and to Henri Bocquillon, for his botanical and therapeutical studies of tropical plants; 2500 francs from the interest on the Breant prize to $\mathrm{M}$. Brumpt, for his work on parasitology; the Godard prize to Noël Halle, for his researches on chronic renal tuberculosis; a mention to Henri Vignes, for his notes and researches on menstruation; the Baron Larrey prize is not awarded; the Bellion prizè to Henri Gougerot, for his memoir on the treatment of syphilis in practice; a very honourable mention to Emile and Camille Guillot, for their work entitled "The Healthy House"; the Mège and Argut prizes are not awarded; the Chaussier prize is not awarded, but an encouragement (500 francs) is given to Raoul Benon, for his book on posttraumatic psychic and nervous troubles; the Dusgate prize is not awarded, but Arcangelo Creazzo receives a mention for his work on real and apparent death.

Physiology.-The Montyon prize to André Thomas, for his work on the brain; the Philipeaux prize to Henri Stassano, for the whole of his work in physiology; the Lallemand prize between Jules Glover (Iooo francs), for his work on the physiology of the voice applied to art and industry, and Pierre Achalme (80o francs), for his book on electrotonics and biology; no memoirs have been received dealing with the subject proposed for the Pourat prize, and the prize is postponed to I917; the Fanny Emden prize to Jean Chatanay.

Statistics.-The Montyon prize (1000 francs) to Fernand de Montessus de Ballore, for his seismological work.

History of Sciences.-The Binoux prize between Albert Anthiaume, for his work on the history of nautical science, F. Marguet, and George Sarton.

General Prizes.-Berthelot medals to Gabriel Bertrand, M. Viguier, and Paul Pascal; the Becquerel prize between M. Arnaud (2000 francs), Jean Merlin (7.50 francs), and M. Rabioulle (750 francs); the Gegner prize (3800 francs) to G. Cesaro, for his work in descriptive crystallography; the Lannelongue fund, the interest is divided between Mme. Cusco and Mme. Rück; the Gustave Roux prize to Lucien Berland, the prize reserved from roI4 to Georges Lery; the Tremont prize to Charles Frémont; the Wilde prize to Commandant Batailler, for his work in experimental mechanics relating to ballistics; the Lonchampt prize to Fernand Jadin and Albert Astruc, for their work on the presence and estimation of arsenic and manganese in the vegetable kingdom; the Saintour prize to $\mathrm{A}$. Blonde1. for his work on the theory of tides: the Henri de Parville prize between Jean Escard (I000 francs), for his books dealing with scientific and technical questions, Gustave Loisel (rooo francs), and Albert Buisson (500 francs): no memoir dealing with the subject proposed for the Vaillant prize was received, and the prize is postponed to Inig: the Grand prize of the Physical Scienres to Henrv Hubert, for his study of the geolory of French Western Africa; the Le Conte prize to Sir Almroth Wright, for his researches in antityphoid vaccination; the Petit d'Ormov and Laplace and Rivot prizes are not awarded.

\section{WIRELESS COMMUNICATION.}

SOME notes on the present state of wireless telegraphy were communicated by Dr. M. I. Pupin in the course of a lecture which he delivered before the National Academy of Science in New York, on "Aerial Transmission Problems." None of the points raised by Dr. Pupin were entirely new, as they have been frequently discussed in both continents without being appreciably helped towards solution. But the manner in which they were presented and illustrated assisted towards a better understanding of the formidable character of the obstacles in the way of extending the distance of wireless communication. These obstacles are due mainly to the interference produced by electrical waves, which are passing through the terrestrial atmosphere continuously, and it is not until we attempt to magnify the minute signais coming from a distant transmitting station that we are really aware of their presence. An engineer who took part in the recent long-distance wireless telephony trials and listened for the famous telephone message from Arlington, reports that at times "it was drowned completely in a roar of musketry," due, of course, to the action of the electrical waves produced by the incessant electrical discharges in the atmosphere. All attempts up to the present which the "practical" wireless engineer has made in the direction of overcoming these disturbances have consisted in increasing the power applied at the transmitting station so as to make the incoming signals at the receiving station stronger than the signals made by the "static." Ordinary electrical tuning is not sufficient for the purpose, because every system which is highly selective through ordinary tuning is also highly sonorous every tap of the static will cause it to vibrate, and it will vibrate in the same way as when it is under the action of the signalling waves. The method advocated by Dr. Pupin involves the use of a sectional wave conductor between the antenna and the receiving apparatus, which will not transmit electrical waves of a frequency higher than a given range of frequencies. By this means, he states, "the station becomes an ear, which is quite sensitive for frequencies which are in the vicinity of the signalling frequency, which is deaf to frequencies which are considerably beyond this range, as most static disturbances are." "Similarly," he adds, " a sectional wave conductor can be constructed which is quite responsive to frequencies in the vicinity of the signalling frequency, but absorb almost completely everything below this range.'

Dr. Pupin corrects the popular misconception that wireless telegraphy formed its first roots in German soil, whereas in reality it is a particular case of the oscillatory motion of electricity discovered by Joseph Henry, and the laws of which were formulated by Kelvin. It is true that Hertz employed these oscillations more skilfully than anybody else did prior to his time, and thereby succeeded in improving experimentally the complete validity of the physical foundation of the electromagnetic theory which was conceived and formulated by Clerk Maxwell, and paved the way for Mr. Marconi. Dr. Pupin claims that "Marconi discovered wireless telegraphy," but he altogether ignores the achievements of Branly, of Lodge, of Popoff, and others. It cannot be said of Mr. Marconi that he discovered the principles or invented the primary appliances upon which the transmission of electromagnetic waves are based. $\mathrm{He}$ accomplished his result by combining, in the utilisation of linown principles, features which had been disclosed by others. which he improved and co-ordinated, with additional features of his own invention.

Mr. E. H. Colpitts, the research engineer of the Western Electric Company of America, under whose direction the apparatus was developed and the experiments conducted which resulted a few weeks ago in the wireless transmission of speech between Arlington, U.S.A., and Honolulu, on one hand, and Arlington and Paris on the other, discusses in the Scientific American the significance of the recent achievement in long-distance wireless telephony. The technical details of the system have already been described, so far as they are available, and chief interest in Mr. Colpitts's article lies in his views regarding the future of wireless telephony. He does not consider that it will displace line telephony, and even if it is physically possible and can be usefully employed, it must fail to be commercially practicable. Atmospheric disturbances were found to be a great drawback, while another difficulty 
revealed in the Arlington trials was the susceptibility of the receiving stations to induction from near-by power circuits or electrical apparatus. With the present limited use of wireless, this latter trouble can be avoided by carefully choosing the sites of receiving stations, but it would become a serious factor if the use of wireless telephony became general. Mr. Colpitts predicts the use of wireless telephony for longdistance communications. Thus a transoceanic telephone cable is not an engineering or commercial possibility; and to enable, say, America to talk to Europe or Asia, wireless telephony will be the means chosen. In extending the possibilities of wireless communication between ships at sea there is a field for telephony, while from ship to shore wireless telephony is the only possibility.

\section{THE TRANSMISSION OF BILHARZIA DISEASE BY SNAILS. ${ }^{1}$}

THE cause of Bilharzia disease of man was dis covered by Bilharz in 1851 , and it is only now, more than half a century later, that the mode of transmission has been discovered. The disease is due- to the presence of flukes in the mesenteric and vesical veins, or, rather, it is in the main the eggs which these worms lay that cause the inflammation which has such dire consequences. The cause being known, helminthologists of repute then naturally sought to determine how infection arose. It was known that the eggs hatched in water into ciliated embryos, and from what was also known of the life-history of other flukes, it was natural to conclude that in this case also the embryos next entered into the tissues of some fresh-water mollusc. This could be shown in two ways, either (I) by experimentally infecting molluscs with the larval forms (ciliated embryos), or (2) by dissecting molluscs from an endemic area and finding the larval forms in them. All attempts in these directions proved in vain. But it is astounding to learn in this report that whereas some fifty species of freshwater molluscs occur in Egypt, only nine species are recorded as having been examined by the various observers who took up the problem. Nine species out of fifty! One cannot help adding that these observers really deserved their bad luck not to have by accident stumbled on the right mollusc.

Before, however, we proceed to describe how Dr. R. T. Leiper, who conducted this expedition, found the intermediate host (mollusc) we should point out at what stage our knowledge had previously arrived.

In Japan there exists in man and dogs a "Bilharzia" disease due to a different species of fluke, but to one belonging to the same genus. Japanese workers had shown that dogs could be infected by standing them in the water of flooded fields of infected areas, but not in water containing simply ciliated embryos, and they noted that the invading form differed so much from the ciliated embryos that an intermediate host seemed probable. Further, in I9I3 it was announced that a reproductive stage of this fluke had been found in Lymnæus sp. Mice were a!so infected from the water in which snails had lived, these having been previously infected with larval stages. These results were fully confirmed and extended by Leiper and Atkinson in Japan. The problem of the Egyptian bilharziasis was now ripe for solution, and we see in the present report how rapidly Leiper and his colleagues effected it. On p. 23 it is stated the mission found bilharzia worms in three species out of eight of the commonest fresh-water molluscs within half an hour's train journey from Cairo!

1 Report on the Results of the Bilharzia Mission in Egypt, rgr5. Bv Tempnrary Lieutenant-Colonel R. T. Leiper. Journal of the Roval Army Danielsson )

$$
\text { NO. 24II, VOL. 96] }
$$

Other workers aware of the Japanese results were also attacking the problem. In July, 19I5, Causton and Warren published the resuits of their experiments. Though they hesitated in forming a definite conclusion, it now appears certain that the cercariæ they found in Physopsis africana were those of bilharzia.

To return to the present report. At El Marg, a village where the only water supply is a branch of the fresh-water canal from Cairo to Ismailia and Port Said, forty-nine out of fifty-four boys of about twelve years of age were found to be infected. Fifteen species of molluscs were found in the canal when the water in the latter was turned off, which occurs for a fortnight every three weeks. The commonest species were Planorbis boissyi, bullinus, and cleopatra spp. The two former species "attracted" ciliated embryos of bilharzia eggs when these were presented to them in water.

$P$. boissyi was so commonly infected with bilharzia cercariæ (larval forms) that large quantities of cercariæ could easily be collected. Rats were successfulty infected with these cercariæ, and the adult worms were found in the portal veins. An examination of the eggs proved them to be the human species. Experiments on monkeys now showed that the oral as well as the cutaneous modes of infeetion occurred, but the oral probably means mucosal and not gastric. The incubation period was one-two months in these animals, as it is in man. The main fact has now been discovered. There will remain the working out of details. Further work will be necessary on the life-history of the snails, and it will perhaps be wise to wait until we know this thoroughly before precise measures of prophylaxis are advocated, but we may point out some of the factors bearing on the problem.

The disease is commoner in the Delta and in the Fayum than in those parts of Egypt supplied with "basin" irrigation. For instance, as Madden has pointed out. Ghizeh furnishes to Cairo hospitals only about ten cases per Ioo,ooo population, while Sharkieh furnishes twenty, Qaloubieh eighteen, and Menoufieh about thirteen. These latter provinces have perpetual irrigation, while Ghizeh has basin irrigation. The probable explanation is that perpetual irrigation favours the development of snails.

There are 30,000 children born annually in Cairo; 10,000 of these, it is said, become infected. How? Cairo has two water supplies, a filtered, and an unfiltered derived from the Nile. Now water that has been taken from the Nile and used for agriculture as a rule does not re-enter the Nile, but is removed by drains which eventually reach the sea, but south of Cairo a number of these drains re-enter the Nile, so that this is a possible source of infection of Cairo by its unfiltered water. Cercariæ, however, can only be kept alive experimentally for thirty-six hours in water, and it is calculated that if the water has entered more than thirty miles upstream the cercariæ should be dead before they reach Cairo. As regards the infection in Cairo, one would like to have the actual proof of the finding of cercariæ in the unfiltered water from the pipes. The opinion is expressed that storage for $\mathrm{I}_{2}-2$ days of this unfiltered water would protect Cairo. In villages, the principle involved is a simple one, viz., turning off or diverting the water from a particular canal, with the result of killing the molluscs, but the problem is complicated by a consideration of the agricultural aspect of such a procedure.

It is at present premature to indicate exactly how this can be best done; a very careful study of the life-history of snails will, as we have said, be necessary, but we have no doubt that Egypt can at last be freed from the scourge of bilharzia, evidence of the ravages of which has been found even in the mummies. J. W. W. S. 